\title{
Obituary
}

\section{SIR J. ARThur Thomson}

$\mathrm{W}$ ITHIN two years of his retirement from the chair of natural history at the University of Aberdeen, Sir J. Arthur Thomson was struck down by a heart illness which had hampered his wellbeing for many years, and although he rallied, his power of resistance was broken and he died at his home at Limpsfield in Surrey on February 12, aged seventy-one years.

Born at Saltoun, East Lothian, on July 8, 1861, a son and grandson of the manse, Thomson graduated M.A. at the University of Edinburgh in 1880, and thereafter completed the divinity course at New College. But the influence of his teachers, and a natural bent derived from two generations of naturalists on his mother's side, swung the balance towards the study of natural science, and in 1883 he was at Jena under the guidance of Ernst Haeckel, and in 1885 with Schulze at the Zoological Institute in Berlin. He returned to Edinburgh to become the most popular teacher of his time in zoology and botany, and his success there led to his appointment in 1899 to the regius chair of natural history at Aberdeen. He was a good teacher, clear and sympathetic, never losing sight of the wood for the trees, insistent upon the broad truths to which the facts pointed; and so during these thirty-one years he kept turning out a stream of scientific workers remarkable in its volume for a small university recruited from schools where biology is unknown.

At the same time, Thomson was constantly engaged upon systematic investigations of the Alcyonaria, collections of which came to him for identification from almost all the seas of the world. The majority of his papers upon these collections were included in the reports of special expeditions, so that the mass of his descriptive work has been scarcely recognised ; but although it was perhaps the least important of his great activities, it was very far from being negligible, as is witnessed by the extent of the collection of type and named specimens he presented to the British Museum on his retirement, and by the excellence of such memoirs as his accounts of the Alcyonaria of the Australian Thetis Expedition, of the Prince of Monaco's collection, and of the Dutch Siboga Expedition to the East Indies, the last of which appeared not many months ago.

Apart from his teaching, Thomson's great achievement was undoubtedly as an expositor of science and scientific thought. He had a gift of simple, lucid writing and lecturing, which enabled him from his full knowledge to expound the beauty and interest of Nature, so that no man of his time has done so much to interest the people in natural history. That was a work of importance, paving the way for that appreciation of scientific work which will allot to it its proper place in the life and progress of civilisation. $\mathrm{He}$ was in demand at home and abroad as a lecturer, and his lectures in book form, together with his other writings, make a considerable library in themselves. They were by no means all of the popular sort, and amongst the best I should be inclined to place "The Evolution of Sex" (1889) written with Patrick Geddes, "The Science of Life" (1899), a neat summary of biological progress, "The Wonder of Life" (1914), the St. Andrews Gifford lectures "The System of Animate Nature" (1920), the "Biology of Birds" (1923), and his last great work, written again with Geddes, "Life: Outlines of General Biology" (1931), a store-house of biological themes. On the popular side, the larger works which were probably most widely read were "The Outline of Science" which he edited and mostly wrote, and "The New Natural History".

Many honours came to Sir Arthur: he was invited to give several important series of lectures in Great Britain, in South Africa and America; he was created a knight on retirement from his chair, and then also Aberdeen made him an LL.D., a degree which had already been conferred upon him by his own University of Edinburgh, and by McGill University and University of California. Throughout it all he preserved a charmingly simple, almost shy demeanour, which hid a warm heart and much friendliness.

Sir Arthur Thomson could not have accomplished his vast output without the active assistance of Lady Thomson, herself a naturalist, and it is evidence of the strength of heredity and of the influence of early nurture, that each of the members of their family, three sons and a daughter, has contributed to scientific literature.

JAMES Ritchie.

\section{Prof. A. H. Sayce}

WITH the passing of Archibald Henry Sayce on February 4, Oxford loses one of the last, if not the last, of the old life-fellows, and the world a link with the scholars, of whom Sayce was by no means the least, who first deciphered the languages of the inscriptions of the old tongues of Mesopotamia and the surrounding regions, and so put on a firm basis the study of the ancient history of the Nearer East.

Sayce was in many respects a most remarkable man. He was born so far back as 1846 , the oldest son of the Rev. H. S. Sayce, vicar of Caldicot, Mon., and even in undergraduate days had the misfortune to have bad health, but he was endowed with a remarkable persistence, and a scarcely less remarkable memory. He found the handling of heavy texts, lexicons and dictionaries an unpleasant task, and certainly for very many years abandoned their use, preferring to quote, not always perhaps accurately, from his well-stored memory. It is perhaps to this fact that we owe the enormous breadth of his learning, for he remembered all he read and up to the very last was reading and annotating with many linguistic 
parallels the latest current periodicals. He always moved with the times.

Sayce's early interests were mainly of a philological nature, including not only technical work on ancient languages, but also services to the revisers of the Old Testament, and a text and commentary on Herodotus. Later, he turned to questions of comparative religion, and when he was already more than sixty years of age, pure archæology especially attracted him. He acquired. a very complete knowledge of modern work on prehistoric archæology, and the present writer remembers discussing with him, in his eightieth year-and it was Sayce who did most of the discussing - the problems of Mousterian and Upper Palæolithic flints in Transjordan. The geographical and scientific side of Assyriology was always of great interest to him, possibly owing to his early training under the Rev. Bradford Waring Gibson of Trinity College, Cambridge, a keen student of mathematics who was headmaster of Grosvenor College, Bath, where Sayce was educated. Unfortunately, apart from such publications as his "Notes on an Unexplored District of Northern Syria" in the Proceedings of the Society of Biblical Archoeology of 1911, most of his geographical work is buried in former editions of the "Encyclopædia Britannica".

In addition to these wide interests, Sayce was an admirable preacher, and a pleasant and witty companion even to those widely separated from him in years, and it is sad to think that he no longer occupies the rooms in Queen's which he has had since he first became a fellow, nor shall we see any more the frail figure of our old friend walking along the sunny side of the Banbury Road on his way to visit one of his many pupils, for so we were, though he never gave and, indeed, of later years disliked, formal teaching.

Sayce obtained a first-class both in Moderations and Greats, taking his final Schools in 1868, a year which included Andrew Lang, E. A. Knox, afterwards Bishop of Manchester, T. Humphrey Ward, and K. A. Muir-Mackenzie. He obtained his fellowship in 1869, and was classical and theological tutor from 1870 until 1879. He was a member of the Old Testament Revision Company from 1874 until 1884, and deputy professor of comparative philology from 1876 until 1890 ; in the following year he became professor of Assyriology, and resigned in 1914. In 1897 he became president of the Society of Biblical Archæology, and retained this position until the Society was amalgamated with the Royal Asiatic Society in 1918. He was Hibbert lecturer in 1887, Gifford lecturer in 1902, when he discussed "The Conception of the Divine among the Egyptians and Babylonians", Rhind lecturer in 1907 and Huxley lecturer of the Royal Anthropological Institute in 1930. His honours were naturally mainly academic. His old University made him an Hon. D.Litt. in 1907, he was an honorary fellow of the British Academy and Hon. LL.D. of Dublin, and also held the honorary degree of D.D. at Edinburgh and Aberdeen.
It is not possible to recount Sayce's many publications. His first publications were Assyrian grammars; in 1874 he published "Principles of Comparative Philology" and six years later "Introduction to the Science of Language". Perhaps his best-known work is "Fresh Lights from the Monuments" which passed through no less than nine editions between 1883 and 1895, while his standard book on the Old Testament was " "Higher Criticism' and the Verdict of the Monuments" (1894). This does not include a host of other books and articles, some of which have been mentioned above, for, during his long working life, scarcely a year passed without an important contribution from his pen dealing with some aspect of Assyriology.

L. H.D. B.

\section{Mr. T. A. CoWARD}

THE sudden death from heart failure of Thomas Alfred Coward at his home at Bowdon on January 28 leaves a gap in the ranks of British field naturalists and came as a blow to those who knew and loved him.

Coward was born in Bowdon, a Cheshire suburb of Manchester, in January 1867, and there he spent his life. Educated at Brooklands School, Sale, and Owens College, Manchester, he endured nineteen years in the uncongenial atmosphere of a Manchester warehouse, until the absorption by one of the large industrial combines of the firm which he was serving gave him the chance he craved, and for more than thirty years he was able to follow his own bent in studying animals, particularly vertebrates, in the field. He contributed occasional notes and papers to the Proceedings of the Zoological Society, to the Zoologist, British Birds and other more or less technical magazines. Articles in the Field and other newspapers and in the Nineteenth Century appealed to a larger public, and as "T. A. C." of the Manchester Guardian he was widely known.

Of Coward's many books on topography and natural history, the most serious contribution to scientific literature was perhaps the "Vertebrate Fauna of Cheshire and Liverpool Bay" (1912), which ranks high among county faunas, but better known is his "Birds of the British Isles and their Eggs", first issued in 1919, a household word among amateur ornithologists, which has done more to promote and encourage the intelligent study of birds in Great Britain than any other work of our time. To study birds he went to many out of the way parts of Britain from the Shetland Isles to Cornwall, and with his wife, who shared his tastes, visited Holland, the Camargue, the Pyrenees and Hungary in order to find birds he could not see at home.

What Coward wrote was always good reading. It was mostly the outcome of his own wide and varied experience, was free alike from technicalities and rhetorical frippery, and above all was accurate. He had a considerable vogue as a lecturer and his lectures and broadcast talks were compact of the 